\title{
Influenza, Malaria parasitaemia and Typhoid fever Coinfection in Children: Seroepidemiologic Investigation in Four Healthcare Centres in Lagos, Nigeria
}

AbdulAzeez Adeyemi Anjorin ( $\square$ abdul-azeez.anjorin@lasu.edu.ng)

Lagos State University https://orcid.org/0000-0002-4152-8659

Shola R Babalola

Lagos State University

Oluwaseun P lyiade

Lagos State University

Research article

Keywords: Influenza virus, Malaria parasitaemia, Typhoid fever, Seroepidemiology, Nigeria.

Posted Date: August 30th, 2019

DOl: https://doi.org/10.21203/rs.2.13737/v1

License: (c) (i) This work is licensed under a Creative Commons Attribution 4.0 International License.

Read Full License 


\section{Abstract}

Background: According to WHO, out of about one billion individuals usually infected with influenza virus, children from developing countries account for $99 \%$ of deaths due to related infections. There is dearth of clinical-epidemiological information on the trio of influenza, malaria, and typhoid fever co-infection in Nigeria. Similarity of their clinical symptoms coupled with lack of vaccine and all year-round circulation in sub-Saharan Africa cause serious paediatric morbidity and mortality. This study therefore investigated influenza, malaria and typhoid fever coinfection among children in Lagos, Nigeria. Methods : A seroepidemiologic hospital-based study was designed. Blood from 364 children tested by RDT for malaria HRP-II/pLDH (Accessbio or Medicon BioCheck, USA) and typhoid (CTKBiotech, USA or Omega, UK) were screened by ELISA (Demeditec, Germany) for influenza virus specific IgM antibody. Descriptive statistics was used and p-values were determined with Chi-square. Results : Demographic data showed median age of 3 (mean 3.8, mode 2, range 0-14) years. Out of the 364 samples tested, 76/364 (20.9\%) were seropositive for influenza A virus. Of the 76 seropositive patients, $47 / 76(61.8 \%)$ had malaria parasitaemia, $42 / 76$ (55.3\%) had typhoid, and 21/76 (27.6\%) were co-infected with malaria parasitaemia and typhoid fever. Furthermore, 2/76 (2.6\%) children having underlying health condition of sickle cell anaemia recorded influenza seropositivity. Ojo primary healthcare centre had the highest seroprevalence of $48.7 \%$ (37/76), age group $1-4$ years recorded the highest seroprevalence of $55.3 \%(42 / 76)$, the highest serologic evidence of $61.8 \%$ (47/76) was detected among male children, while fever $27.6 \%(21 / 76)$ was the most common of all the clinical symptoms recorded. Although, the month of March had the highest seroprevalence of $20 / 76(26.3 \%)$, seropositivity was recorded in all other months considered for this study. Conclusions : We hereby report the first paediatric co-infection of influenza, malaria and typhoid fever with a percentage seroprevalence of $27.6 \%$ among all age group round the months. Low coinfection was however recorded in children having sickle cell anaemia. Annual vaccination is strongly recommended for children of all ages in order to prevent co-infection of influenza with other deadly diseases.

\section{Background}

Influenza, an infectious respiratory disease caused by enveloped RNA virus of the family Orthomyxoviridae, is largely spread via aerosols and droplets generated through coughing and sneezing $[1,2]$. Annually, influenza virus infect about one billion individuals with resultant 3-5 million severe cases and 290,000 to 650,000 deaths globally [3, 4]. It affects individuals of all ages including children, especially those with underlying health conditions $[5,6]$. Children account for $20-30 \%$ of the annual attack with those from developing countries recording $99 \%$ of deaths due to influenza related infections [4]. Over 250,000 African children, less than 5 years are hospitalized with influenza and have annual influenza associated hospitalization rate three times higher than the children in developed countries [7]. Unfortunately, in Nigeria, there is lack of a national policy on vaccination against this vaccine preventable disease either in the general population or among the high risk group. 
Malaria on the other hand, is a parasitic disease caused by a single-celled protozoan of the genus Plasmodium belonging to the phylum Apicomplexa [8]. It is spread from person to person through the bite of infected female Anopheles mosquito [9]. Out of the 3.2 billion people at risk of malaria infection, about 214 million cases occur yearly particularly in Africa with Nigeria having the highest number of cases [10, 11]. It leads to 438,000 deaths with sub-Saharan Africa accounting for $90 \%$ [11], of which more than twothird occur in children less than 5 years old [12]. In Nigeria, malaria accounts for $60 \%$ of outpatient visits, $30 \%$ child mortality and $11 \%$ of maternal mortality [13]. Generally, children with malaria often present with fever, chills, headache, myalgia, and vomiting which is similar to some of the influenza symptoms [14].

Typhoid fever is a systemic infection caused by Gram negative bacterium Salmonella enteric Typhi (S. Typhi) which is transmitted from person to person through faecal-oral route [15]. Symptoms include fever, diarrhoea, loss of appetite and abdominal cramp [16]. Typhoid fever remains a significant health problem particularly among children and adolescent in developing countries [17] as a result of poor sanitation and unsafe food and water supply usually contaminated with human faeces [18]. In some areas, the incidence rate occurs among children below 5 years [19]. However, it was estimated in 2010 that typhoid fever caused 26.9 million cases with 217,000 deaths globally [20].

Children in sub-Saharan Africa including Nigeria are vulnerable to influenza, malaria and typhoid coinfection with little or no information on their coexistence. Therefore, this study was aimed to determine the seroprevalence of influenza, malaria and typhoid fever coinfection in children from different healthcare centres in Lagos, Nigeria.

\section{Methods}

\section{Study site and subjects}

A prospective cross-sectional sero-epidemiologic hospital-based study was designed. In and out-patients were recruited from government/ public health institutions in four different locations including Festac (Maternal and Child health), and three primary health centres (PHCs) of Amuwo, Ojo and Shibiri in Lagos State. The PHCs were chosen based on different local council development areas with close proximity to the University research laboratory in Ojo town, availability of screening facilities for routine malaria and typhoid tests, and the population of nursing mothers attending such centres for paediatric treatment. The maternal and Child centre is a reference paediatric centre for the treatment of infants, and children. It also provides pre-natal, postnatal, family planning and other medical services to mothers. Blood were collected from unvaccinated children between the months of March to October, 2018. The concept of the study was explained to their parent/ guardian and their consent sought. Information on demography, clinical symptoms, and other epidemiological parameters under confidential disclosure were appropriately collected with interviewer questionnaire printed-forms by trained Scientists and laboratory personnel.

\section{Study population}


In- and out-patients' from both sexes and age group 0 - 14 years particularly those having influenza-likeillness (ILI) of fever above $38^{\circ} \mathrm{C}$, runny nose/ catarrh and cough were recruited. Malaria and typhoid tests were routinely requested by the clinician for such children, while influenza was performed for the purpose of the study. The study excluded adults, patients without fever and those not tested for malaria and typhoid. The minimum sample size was determined using Kish, Leslie formula of $n=Z^{2} p(1-p) / d^{2}$, where $Z=$ reliability coefficient of 1.96 at $95 \%$ confidence interval. A presumed prevalence of $18.9 \%$ was used according to [21].

\section{Ethical Approval and Permission}

Ethical approval was obtained from the Health Research and Ethics Committee of Lagos State University Teaching Hospital (LASUTH) Research and Ethics Committee (LREC) with reference number: LREC.06/10/1030 while each hospital/ centre permission was sought from the head of the health centre/ hospital where the samples were collected.

\section{Sample collection and preservation}

Five (5) mls of blood samples were aseptically drawn by the phlebotomists or midwives using sterile needle and syringe. Each blood sample was shared into labeled EDTA and plain container for malaria/ typhoid and influenza viral assay respectively. Malaria and typhoid samples were further processed at the $\mathrm{PHC}$ of collection while sample aliquots for influenza viral assay were then kept in the coolers with icepacks before being transported to the laboratory. Sera were separated from the blood by centrifugation at $3000 \mathrm{rpm}$ for 10-15 minutes and transferred into labeled cryovial tubes with the aid of Pasteur pipettes, before they were stored at $-30^{\circ} \mathrm{C}$ until ready to use.

\section{Laboratory analyses}

Laboratory analysis was performed at the Virology Research Laboratory, Department of Microbiology, Lagos State University, Ojo. All the children tested by Rapid Diagnostic Test (RDT) for the detection of malaria histidine-rich protein II (HRP-II) and Plasmodium lactate dehydrogenase (pLDH) (Accessbio or Medicon BioCheck, USA) and typhoid (CTKBiotech, USA or Omega, UK) (depending on the type of assay kit in use at the $\mathrm{PHC}$ ), were further screened for the qualitative and quantitative determination of influenza virus specific IgM antibody by ELISA (Demeditec, Germany). Characteristics of the assay kit include: $100 \%$ clinical specificity and $100 \%$ sensitivity with no cross-reactivity to RSV, Adenovirus and Parainfluenza 1/2/3 according to the manufacturer.

Briefly, for the malaria and typhoid RDTs performed at the PHCs, whole blood or plasma (as indicated in the manufacturer's assay procedure) was applied into the sample pad. Buffer solution (2 drops) were added (when whole blood sample was used) into the test kit round hole. Result was read and interpreted after about 10-15 minutes. Appearance of line in both the control and test region was recorded as positive result, otherwise, the result was negative or invalid. Invalid results were however repeated. 
For the ELISA, micro titer wells were labeled for the standards, controls and samples as well as for substrate blank. The samples were diluted with ready to use sample diluents provided with the test kit in the ratio 1:101 ( $1 \mu \mathrm{l}$ serum $+100 \mu \mathrm{l}$ sample diluents). $100 \mu$ of the ready to use standard controls and diluted samples were pipetted into the micro titer wells leaving one well empty for the substrate blank. The micro plate was covered with re-usable plate cover and incubated at room temperature for 60 minutes. Unused reaction fluid was emptied and $300 \mu \mathrm{l}$ of diluted washing solution was added. The wells were washed three-times while remnant fluid was removed by gently tapping the micro titer plates on disposable papers. Ready to use enzyme conjugate (100 $\mu$ l) was added into the wells leaving one well for the substrate blank. The microplates were covered with re-usable plate-cover and incubated at room temperature for 30 minutes. The plates were emptied and another $300 \mathrm{I}$ of diluted washing solution was added (three times) for washing. Remnant fluid was again removed by tapping the plate gently on disposable papers. Ready to use substrate $(100 \mu \mathrm{l})$ was added into the wells and the substrate blank. The plate was covered and incubated at room temperature in the dark for 20 minutes. A blue colour was observed before the substrate reaction was terminated with $100 \mu \mathrm{l}$ of ready to use stop solution. A yellow colour developed while the absorbance of the wells was read with ELISA microplate reader (Emax precision, Molecular Devices, California, USA) at $450 \mathrm{~nm}$ wavelength. Each assay batch was performed with positive and negative controls. All the test results were expressed based on the standard curve provided with the assay kit supplied by the Manufacturer. Samples were considered positive if the antibody concentration was $>1.148 \mathrm{U} / \mathrm{mL}$ based on cut-off specification of the manufacturer. Positive influenza virus-specific lgM antibody has the implication of recent immunological response to infection with circulating influenza strains in the population as influenza vaccination is not practice in Lagos and Nigeria in general.

\section{Statistical Analysis}

Epidemiological data were systematically analysed using GraphPad Prism Version 8.0.1 (244), San Diego, USA. P-values and statistical significant differences $(p<0.05)$ between categorical data were measured using Chi-square.

\section{Results}

This prospective study investigated a total of 364 children having ILI from 4 health centres in Lagos (Fig. 1). They were previously screened for both routine malaria and typhoid fever tests while this study further examined those with both malaria and typhoid result outcome for possibility of co-infection with influenza virus. Out of the 364 blood samples investigated for IgM antibody specific to influenza virus, $20.9 \%$ (76/364) were seropositive. Of the 76 influenza seropositive children, $61.8 \%$ (47/76) were positive for malaria, 55.3\% (42/76) were positive for typhoid, and 27.6\% (21/76) had co-infection of both malaria parasitaemia and typhoid fever (Fig. 2).

Out of the 76 influenza seropositive patients, Ojo primary health centre had statistically significant highest seroprevalence of $48.7 \%$ (37/76) while the lowest $13.2 \%$ (10/76) seroprevalence was detected in 
Festac town area of Lagos State. The highest seropositivity of $55.3 \%(42 / 76)$ was obtained in the age group 1-4 years while age 0-5 months recorded the lowest prevalence of $4 \%(3 / 76)$. The observable difference $(p=0.0001)$ was statistically significant. Of the 207 males examined, $61.8 \%(47 / 76)$ were seropositive to influenza virus compare to $38.2 \%$ (29/76) out of the 157 female children examined. The difference was however not statistically significant. In addition, 2/76 (2.6\%) children having underlying health condition of sickle cell recorded influenza seropositivity (Table 1).

Figure 3 shows the clinical symptoms of seropositive children to influenza having co-infection of both malaria parasitaemia and typhoid fever. Fever $27.6 \%(n=21)$ was the most common of all the clinical symptoms recorded.

Although the month of March had the highest seroprevalence of $26.3 \%(20 / 76)$, seropositivity was recorded in all other months considered for this study (Fig. 4).

\section{Discussion}

Enzyme linked immunosorbent assay (ELISA) is a sensitive and quantifiable diagnostic method that has been used in the detection of different aetiologies [22]. Sera antibodies are often used to correlate influenza detection in the assay [23]. This study detected a total percentage seroprevalence of $20.9 \%$ to influenza virus among paediatric patients attending different healthcare centers in Lagos, Nigeria. Healthcare attendees were studied in order to increase the likelihood of detecting exposure of humans to the pathogens since parents of children with febrile illness or influenza-like illness are more likely to seek healthcare attention. The finding is similar to the prevalence of $22.1 \%$ influenza infection reported in Russian children between 2013 and 2017 [24]. A study conducted in Germany (2008- 2010) showed a higher IgG seroprevalence of $87.6 \%$ to influenza virus using ELISA technique [25]. The observable difference could be due to the measurement of $\mathrm{lgG}$, an indication of past exposure to infection compared to the IgM ELISA used to measure recent infection in this study.

On the contrary, Dilantika, Sedyaningsih [26], Norowitz, Kohlhoff [27], and Alsuwaidi, Al-Mekaini [28] using ELISA method reported lower seroprevalence of $11.6 \%$ and $14.9 \%$, and $15.8 \%$ respectively to influenza virus in children. In Africa, studies have reported influenza in pregnancy, HIV patients, sickle cell anaemia patients, and tuberculosis patients with prevalences of $48 \%, 3.9 \%, 2.0 \%$, and $10 \%$ respectively [29-32] while others have shown co-infection of influenza with asthma, pneumonia and malaria but there is dearth of information on co-infection of influenza with typhoid fever, and malaria and typhoid, hence the importance of this study.

Our findings showed that a good number of children having monotypic seropositivity to influenza virus had co-infection with malaria parasitaemia and/or with typhoid fever with $61.8 \%$ co-infection of influenza and malaria higher than that of $55.3 \%$ for influenza and typhoid, and $27.6 \%$ co-infection of the trio of influenza, malaria and typhoid. Studies have shown that influenza is one of the viruses that may lead to complication of malaria infection [33,34], while findings from this study is suggestive of malaria parasitaemia complicating influenza infection in children. However, Thompson, Breiman [35] reported 
uncommon co-infection of malaria and influenza in Kenya in 2009-2011. A good reason for this might be that both malaria parasitaemia and influenza can be sub-clinical or incidental to the presenting illness $[36,37]$.

Our findings of $55.3 \%$ monotypic infection of influenza, 31.9\% co-infection of influenza and malaria, $50 \%$ coinfection of influenza and typhoid, and $42.9 \%$ coinfection of influenza, malaria and typhoid respectively showed that children in the age group 1-4 years were the most affected by all the infections when compared to other age groups and the difference was statistically significant (Table 1). This is a pointer that children of age 1- 4 years had the highest recent exposure to influenza virus, mosquito bite and contamination with $S$. typhi, that call for urgent and serious public health attention. The influenza monotypic infection unlike influenza, malaria and typhoid co-infection is consistent with the study of Tempia, Walaza [38] that reported a similar prevalence of influenza virus in children less than 5 years of age. Studies from India and Bangladesh also reported highest prevalence of influenza in children less than 5 years [39, 40]. Gessner, Shindo [36] showed that in Sub-Saharan Africa, children less than 5 years are more exposed to influenza than other age group. According to CDC [41], the highest hospitalization for influenza epidemiology was reported in children age 0-4 years with the lowest prevalence in children of 5-14 years. Our finding is also consistent with that of Riquelme, Torres [42] that estimated high rate of influenza infection in children less than 5 years, unlike Mancinelli, Onori [43]; and Shang, Blanton [44] that concluded that influenza seropositivity was highest among children less than 1 year. This could be argued with the fact that their immune system is immunologically immature, making them to be more susceptible to influenza [45].

The male children had higher $61.8 \%$ (47/76) IgM seroprevalence to influenza virus unlike their female counterpart with $38.2 \%(29 / 76)$. This is similar to the finding reported by Tivane, Daniels [31] that influenza virus is higher among male children. This position was also supported by Mancinelli, Onori [43].

The commonest $27.6 \%(n=21)$ clinical symptom of influenza virus presented in the study was fever. This agrees with the finding of Taşar, Bilge [46] that fever is the commonest symptom of influenza-like-illness.

Exposure to recent influenza activity was confirmed through-out the months in which samples were collected with a higher occurrence recorded in the month of March. This is in line with the findings of Tivane, Daniels [31] which showed that influenza occurred through-out the year but the activity was peak in February and August. In contrast to this study, Sanou, Wandaogo [47] showed that influenza was most prevalent in September to October. The basic difference in the prevalence at each point in time is due to the favourable weather condition.

Children having underlying health condition of asthma in this study tested negative to IgM seroprevalence to influenza virus. This finding agrees with the earlier investigation by Tivane, Daniels [31] which opined that no relationship exist between children having asthma and influenza. However, previous studies have shown correlation between influenza, sickle cell and asthma [48] in support of the $2.6 \%$ seroprevalence of influenza in sickle cell patients detected in this study. This is further supported by Bundy, Strouse [30] that reported prevalence of influenza in children with sickle cell. According to 
Adewoyin [49], Nigeria has $20 \%-30 \%$ carrier rate for sickle cell gene with sickle cell disease affecting $2 \%-3 \%$ of the entire population. However, influenza with malaria parasitaemia and typhoid fever coinfection must be urgently prevented in such individuals in order to prevent likely fatal consequences.

Part of the limitations of this study is that we were unable to further analyse the ELISA positive samples by molecular assay due to limited resources. Therefore, there is need for a future study that can generate nucleotide sequences for global data sharing and possible consideration as vaccine candidates from sub-Saharan Africa.

\section{Conclusions}

Our investigation revealed specific IgM antibody seroprevalence to influenza virus with $27.6 \%$ co-infection of malaria parasitaemia and typhoid fever among children of all age group round the months. Fever represented the most common clinical symptom while low co-infection was recorded in sickle cell anaemia patients. Differential screening is hereby recommended for accurate and effective treatment while annual vaccination is strongly advocated for all children in order to prevent coinfection of influenza with other deadly diseases.

\section{Declarations}

\section{Acknowledgements}

The Directorate of Clinical services and Training / Hospital Research Ethics Committee of the Lagos State University Teaching Hospital are hereby acknowledged for their supports. We are grateful to the Management and Staff of the various health centres where samples were collected, especially parents that volunteered and consented that their children should be recruited into the study. We acknowledge all the Technologists that supported the students' research work. Many thanks to Dr. MI Kazeem, a senior Lecturer in the Department of Biochemistry for revising the manuscript. The abstract for this study was submitted for presentation at the $29^{\text {th }}$ Annual Meeting of the Society for Virology at the Heinrich Heine University, Dusseldorf, Germany in March 20-23, 2019.

\section{Funding}

No funding was received for this research.

\section{Availability of data and materials}

The datasets used and analysed during the study are included within the article. Additional data can be provided from the correspondence upon reasonable request.

\section{Authors' contributions}


Conception and Design: AAA. Execution and Interpretation: AAA, ABS, IOP. Manuscript writing: AAA, ABS. All authors read and approved the manuscript.

\section{Ethics approval and consent to participate}

The study procedure was approved by the Health Research and Ethics Committee of Lagos State University Teaching Hospital (LASUTH) Research and Ethics Committee (LREC) with reference number: LREC.06/10/1030. Written informed consent was obtained from the parent/ guardian of all the participants.

\section{Consent for publication}

Not applicable.

\section{Competing interests}

The authors declare that they have no competing interests.

\section{References}

1. Monamele CG, Njifon HLM, Vernet M-A, Njankouo MR, Kenmoe S, Yahaya AA, et al., Molecular characterization of influenza A (H1N1) pdm09 in Cameroon during the 2014-2016 influenza seasons. PloS one 2019; 141: p. e0210119.

2. Montomoli E, Torelli A, Manini I, and Gianchecchi E, Immunogenicity and safety of the new inactivated quadrivalent influenza vaccine vaxigrip tetra: preliminary results in children $\geq 6$ months and older adults. Vaccines 2018; 61: p. 14.

3. Iuliano AD, Roguski KM, Chang HH, Muscatello DJ, Palekar R, Tempia S, et al., Estimates of global seasonal influenza-associated respiratory mortality: a modelling study. The Lancet 2018; 39110127: p. $1285-1300$.

4. WHO. WHO recommendation on the composition of influenza virus vaccines. 2018 [cited 2018 8th December]; Available from: http://www.who.int/influenza/vaccines/virus/recommendations/en/index.html.

5. Launes C, Rives S, Català A, Berrueco R, Toll T, Camós M, et al., Pandemic influenza A (2009 H1N1) in children with acute lymphoblastic leukaemia. British journal of haematology 2010; 1496: p. 874-878.

6. Livingston RA and Bernstein HH, Prevention of influenza in children. Infectious Disease Clinics 2015; 294: p. 597-615.

7. Lafond KE, Nair H, Rasooly MH, Valente F, Booy R, Rahman M, et al., Global role and burden of influenza in pediatric respiratory hospitalizations, 1982-2012: a systematic analysis. PLoS medicine 2016; 133: p. e1001977.

8. Oboh MA, Ndiaye D, Antony HA, Badiane AS, Singh US, Ali NA, et al., Status of Artemisinin Resistance in Malaria Parasite Plasmodium falciparum from Molecular Analyses of the Kelch13 Gene in 
Southwestern Nigeria. BioMed research international 2018; 2018.

9. Nmadu P, Peter E, Alexander P, Koggie A, and Maikenti J, The prevalence of malaria in children between the ages 2-15 visiting Gwarinpa General Hospital life-camp, Abuja, Nigeria. Journal of Health Science 2015; 53: p. 47-51.

10. Dawaki S, Al-Mekhlafi HM, Ithoi I, Ibrahim J, Atroosh WM, Abdulsalam AM, et al., Is Nigeria winning the battle against malaria? Prevalence, risk factors and KAP assessment among Hausa communities in Kano State. Malaria journal 2016; 151: p. 351.

11. WHO, WHO Global malaria programme. 2015.

12. WHO, Influenza vaccines. Weekly Epidemiology Records 2017; 8033: p. 279-87.

13. Noland GS, Graves PM, Sallau A, Eigege A, Emukah E, Patterson AE, et al., Malaria prevalence, anemia and baseline intervention coverage prior to mass net distributions in Abia and Plateau States, Nigeria. BMC infectious diseases 2014; 141: p. 168.

14. Crawley J, Chu C, Mtove G, and Nosten F, Malaria in children. The Lancet 2010; 3759724: p. 14681481.

15. Wain J, Hendriksen RS, Mikoleit ML, Keddy KH, and Ochiai RL, Typhoid fever. Lancet 2015; 3859973: p. 1136-45.

16. Parikh FS, Management of enteric fever in 2012. Med Update 2012; 22: p. 12-4.

17. Barac R, Als D, Radhakrishnan A, Gaffey MF, Bhutta ZA, and Barwick M, Implementation of interventions for the control of typhoid fever in low-and middle-income countries. The American journal of tropical medicine and hygiene 2018; 993_Suppl: p. 79-88.

18. Adhikari A, Rauniyar R, Raut PP, Manandhar KD, and Gupta BP, Evaluation of sensitivity and specificity of ELISA against Widal test for typhoid diagnosis in endemic population of Kathmandu. BMC infectious diseases 2015; 151: p. 523.

19. Abdulkarim IA and Mohammed MU, Spatio-temporal trends of typhoid fever among youths attending Muhammad Abdullahi Wase Specialist Hospital in Kano Metropolis, Nigeria. Bayero Journal of Pure and Applied Sciences 2017; 102: p. 115-121.

20. Akinyemi KO, Oyefolu AOB, Mutiu WB, Iwalokun BA, Ayeni ES, Ajose SO, et al., Typhoid Fever: Tracking the Trend in Nigeria. The American journal of tropical medicine and hygiene 2018; 993_Suppl: p. 41-47.

21. Dalhatu IT, Medina-Marino A, Olsen SJ, Hwang I, Gubio AB, Ekanem EE, et al., Influenza viruses in Nigeria, 2009-2010: results from the first 17 months of a national influenza sentinel surveillance system. The Journal of infectious diseases 2012; 206suppl_1: p. S121-S128.

22. Thiha A and Ibrahim F, A colorimetric enzyme-linked immunosorbent assay (ELISA) detection platform for a point-of-care dengue detection system on a lab-on-compact-disc. Sensors 2015; 155 : p. 11431-11441.

23. Trombetta CM, Remarque EJ, Mortier D, and Montomoli E, Comparison of hemagglutination inhibition, single radial hemolysis, virus neutralization assays, and ELISA to detect antibody levels 
against seasonal influenza viruses. Influenza and Other Respiratory Viruses 2018; 126: p. 675-686.

24. Kurskaya O, Ryabichenko T, Leonova N, Shi W, Bi H, Sharshov K, et al., Viral etiology of Acute Respiratory Infections in Hospitalized Children in Novosibirsk City, Russia (2013-2017). bioRxiv 2018 : p. 353037.

25. Sauerbrei A, Langenhan T, Brandstädt A, Schmidt-Ott R, Krumbholz A, Girschick H, et al., Prevalence of antibodies against influenza A and B viruses in children in Germany, 2008 to 2010. Eurosurveillance 2014; 195: p. 20687.

26. Dilantika C, Sedyaningsih ER, Kasper MR, Agtini M, Listiyaningsih E, Uyeki TM, et al., Influenza virus infection among pediatric patients reporting diarrhea and influenza-like illness. BMC infectious diseases 2010; 10: p. 3-3.

27. Norowitz YM, Kohlhoff S, and Smith-Norowitz TA, Relationship of influenza virus infection to associated infections in children who present with influenza-like symptoms. BMC infectious diseases 2016; 161: p. 304.

28. Alsuwaidi AR, Al-Mekaini LA, Kamal SM, Narchi H, and Souid A-K, Seroprevalence of influenza A and $B$ viruses among unvaccinated children in the United Arab Emirates: a cross-sectional study. BMC research notes 2017; 101: p. 379.

29. Anjorin A, Oyefolu A, and Omilabu S, Seasonal influenza virus infection among unvaccinated pregnant women in Lagos, Nigeria. International Journal of Infectious Diseases 2018; 73: p. 368.

30. Bundy DG, Strouse JJ, Casella JF, and Miller MR, Burden of influenza-related hospitalizations among children with sickle cell disease. Pediatrics 2010: p. peds. 2009-1465.

31. Tivane A, Daniels R, Nguenha N, Machalele L, Nacoto A, Pale M, et al., Antigenic and genetic characterization of influenza viruses isolated in Mozambique during the 2015 season. PloS one 2018; 137: p. e0201248.

32. Walaza S, Tempia S, Dawood H, Variava E, Moyes J, Cohen AL, et al., Influenza virus infection is associated with increased risk of death amongst patients hospitalized with confirmed pulmonary tuberculosis in South Africa, 2010-2011. BMC infectious diseases 2015; 151: p. 26.

33. Berkley JA, Munywoki P, Ngama M, Kazungu S, Abwao J, Bett A, et al., Viral etiology of severe pneumonia among Kenyan infants and children. Jama 2010; 30320: p. 2051-2057.

34. Scott JAG, Berkley JA, Mwangi I, Ochola L, Uyoga S, Macharia A, et al., Relation between falciparum malaria and bacteraemia in Kenyan children: a population-based, case-control study and a longitudinal study. The Lancet 2011; 3789799: p. 1316-1323.

35. Thompson MG, Breiman RF, Hamel MJ, Desai M, Emukule G, Khagayi S, et al., Influenza and malaria coinfection among young children in western Kenya, 2009-2011. The Journal of infectious diseases 2012; 20611: p. 1674-1684.

36. Gessner BD, Shindo N, and Briand S, Seasonal influenza epidemiology in sub-Saharan Africa: a systematic review. The Lancet infectious diseases 2011; 113: p. 223-235.

37. Olotu A, Fegan G, Williams TN, Sasi P, Ogada E, Bauni E, et al., Defining clinical malaria: the specificity and incidence of endpoints from active and passive surveillance of children in rural 
Kenya. PLoS One 2010; 512: p. e15569.

38. Tempia S, Walaza S, Moyes J, Cohen AL, von Mollendorf C, Treurnicht FK, et al. Risk factors for influenza-associated severe acute respiratory illness hospitalization in South Africa, 2012-2015. in Open forum infectious diseases. 2017. Oxford University Press.

39. Hirve S, Krishnan A, Dawood FS, Lele P, Saha S, Rai S, et al., Incidence of influenza-associated hospitalization in rural communities in western and northern India, 2010-2012: a multi-site population-based study. Journal of Infection 2015; 702: p. 160-170.

40. Homaira N, Luby SP, Petri WA, Vainionpaa R, Rahman M, Hossain K, et al., Incidence of respiratory virus-associated pneumonia in urban poor young children of Dhaka, Bangladesh, 2009-2011. PloS one 2012; 72: p. e32056.

41. CDC, Estimates of deaths associated with seasonal influenza 1976-2007. Morbidity and Mortality Weekly Report 2013; 59: p. 1057-1062.

42. Riquelme R, Torres A, Rioseco ML, Ewig S, Cillóniz C, Riquelme M, et al., Influenza pneumonia: a comparison between seasonal influenza virus and the H1N1 pandemic. European Respiratory Journal 2011; 381: p. 106-111.

43. Mancinelli L, Onori M, Concato $C$, Sorge R, Chiavelli S, Coltella L, et al., Clinical features of children hospitalized with influenza A and B infections during the 2012-2013 influenza season in Italy. BMC infectious diseases 2015; 161: p. 6.

44. Shang M, Blanton L, Brammer L, Olsen SJ, and Fry AM, Influenza-Associated Pediatric Deaths in the United States, 2010-2016. Pediatrics 2018: p. e20172918.

45. Poehling KA, Edwards KM, Weinberg GA, Szilagyi P, Staat MA, Iwane MK, et al., The underrecognized burden of influenza in young children. New England Journal of Medicine 2006; 3551: p. 31-40.

46. Taşar MA, Bilge Y, Soyer ÖU, Yildirim Ş, Taşar M, and Arikan Fí, Risk factors and prognosis in children hospitalized due to pandemic H1N1 influenza A virus infection in Ankara, Turkey. Turkish Journal of Medical Sciences 2012; 423: p. 433-440.

47. Sanou AM, Wandaogo SCM, Poda A, Tamini L, Kyere AE, Sagna T, et al., Epidemiology and molecular characterization of influenza viruses in Burkina Faso, sub-Saharan Africa. Influenza and other respiratory viruses 2018; 124: p. 490-496.

48. Vasileiou E, Sheikh A, Butler C, El Ferkh K, von Wissmann B, McMenamin J, et al., Effectiveness of influenza vaccines in asthma: a systematic review and meta-analysis. Clinical Infectious Diseases 2017; 658: p. 1388-1395.

49. Adewoyin AS, Management of sickle cell disease: a review for physician education in Nigeria (subsaharan Africa). Anemia 2015; 2015.

\section{Tables}

Table 1: Epidemiological Data of Children co-infected with Influenza, Malaria and Typhoid fever in Lagos, Nigeria 


\begin{tabular}{|c|c|c|c|c|c|c|}
\hline Epidemiological Data & $\begin{array}{l}\text { Mal (\%) } \\
(n=248)\end{array}$ & $\begin{array}{l}\text { Typ (\%) } \\
(n=146)\end{array}$ & $\begin{array}{l}\text { Positive for } \\
\text { Flu (\%) } \\
(\mathrm{n}=76)\end{array}$ & $\begin{array}{l}\text { Flu+Mal } \\
(\%) \\
(n=47)\end{array}$ & $\begin{array}{l}\text { Flu+Typ } \\
(\%) \\
(n=42)\end{array}$ & $\begin{array}{l}\text { Flu+Mal+Typ (\%) }(\mathrm{n}=21) \\
P \text { value }\end{array}$ \\
\hline \multicolumn{7}{|l|}{ Location } \\
\hline Ojo & 171 & 100 & 37 (48.7) & $29(61.7)$ & $22(52.4)$ & 13 (61.9) 0.04 \\
\hline Shibiri & (69) & $(68.5)$ & 15 (19.7) & $11(23.4)$ & $8(19)$ & $7(33.3)$ \\
\hline Amuwo & 30 & 20 & $14(18.4)$ & $4(8.5)$ & 7 (16.7) & $1(4.8)$ \\
\hline \multirow[t]{4}{*}{ Festac } & $(12.1)$ & $(13.7)$ & $10(13.2)$ & $3(6.4)$ & $5(11.9)$ & $0(0)$ \\
\hline & 27 & $12(8.2)$ & & & & \\
\hline & $(10.9)$ & $14(9.6)$ & & & & \\
\hline & $20(8)$ & & & & & \\
\hline \multicolumn{7}{|l|}{ Gender } \\
\hline Male & 136 & 85 & 47 (61.8) & $29(61.7)$ & $30(71.4)$ & 13 (61.9) 0.43 \\
\hline \multirow[t]{2}{*}{ Female } & $(54.8)$ & $(58.2)$ & $29(38.2)$ & $18(38.3)$ & $12(28.6)$ & $8(38.1)$ \\
\hline & $\begin{array}{l}112 \\
(45.2)\end{array}$ & $\begin{array}{l}61 \\
(41.8)\end{array}$ & & & & \\
\hline \multicolumn{7}{|l|}{ Age Range } \\
\hline 0-5 months & $17(6.9)$ & $10(6.8)$ & $3(4)$ & $14(29.8)$ & $6(14.3)$ & 5 (23.8) 0.0001 \\
\hline 6-11 months & $24(9.7)$ & $16(11)$ & $7(9.2)$ & $10(21.3)$ & $10(23.8)$ & $3(14.3)$ \\
\hline $1-4$ yrs & 130 & 40 & $42(55.3)$ & 15 (31.9) & $21(50)$ & $9(42.9)$ \\
\hline $5-9$ yrs & $(52.4)$ & $(27.4)$ & 15 (19.7) & $5(10.6)$ & $4(9.5)$ & $4(19)$ \\
\hline \multirow[t]{3}{*}{$12-14$ yrs } & $\begin{array}{l}46 \\
(18.5)\end{array}$ & $\begin{array}{l}51 \\
(34.9)\end{array}$ & $9(11.8)$ & $3(6.4)$ & $1(2.4)$ & $0(0)$ \\
\hline & 31 & 29 & & & & \\
\hline & (12.5) & (19.9) & & & & \\
\hline \multirow{2}{*}{\multicolumn{7}{|c|}{$\begin{array}{l}\text { Underlying Health } \\
\text { Condition }\end{array}$}} \\
\hline & & & & & & \\
\hline Sickle cell & $10(4)$ & $6(4.1)$ & $2(2.6)$ & $1(2.1)$ & $0(0)$ & $0(0)$ \\
\hline Asthma & $0(0)$ & $2(1.4)$ & $0(0)$ & $0(0)$ & $0(0)$ & $0(0)$ \\
\hline
\end{tabular}

Legend: Flu, influenza; Mal, malaria; Typ, typhoid.

\section{Figures}




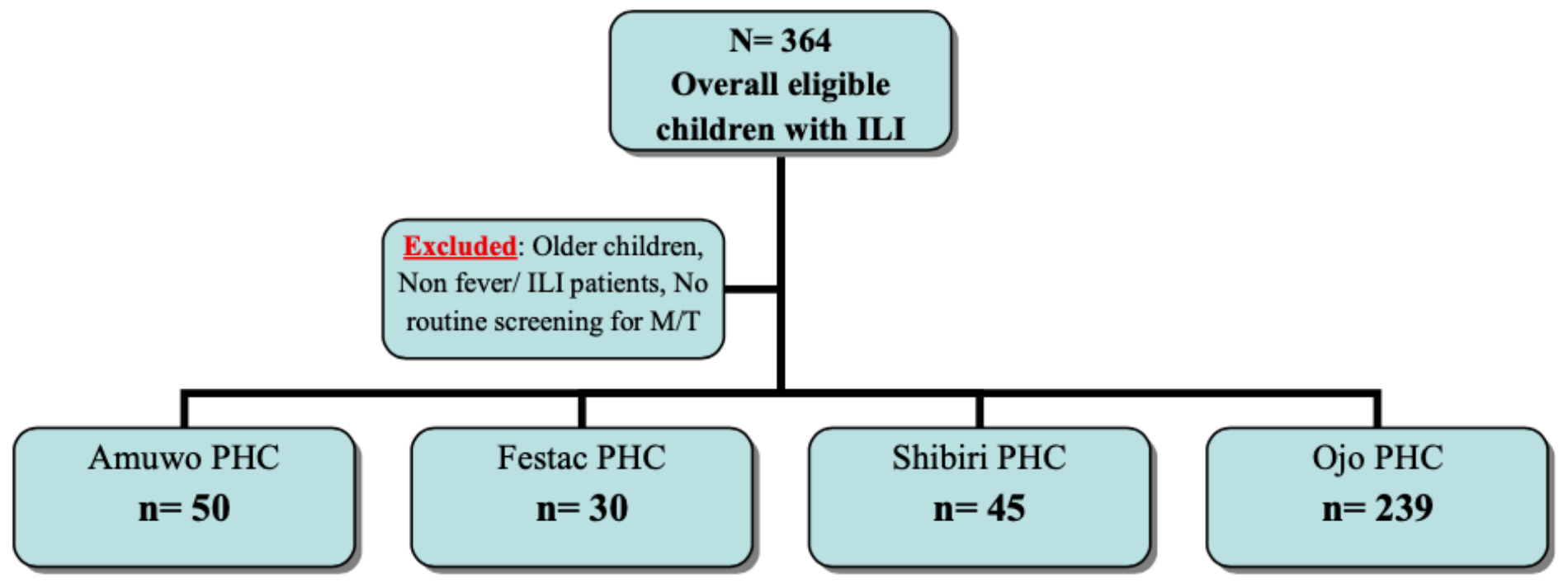

Figure 1

Flow Diagram for inclusion and sampling of children with influenza-like illness (ILI) screened for malaria (M) and typhoid (F).

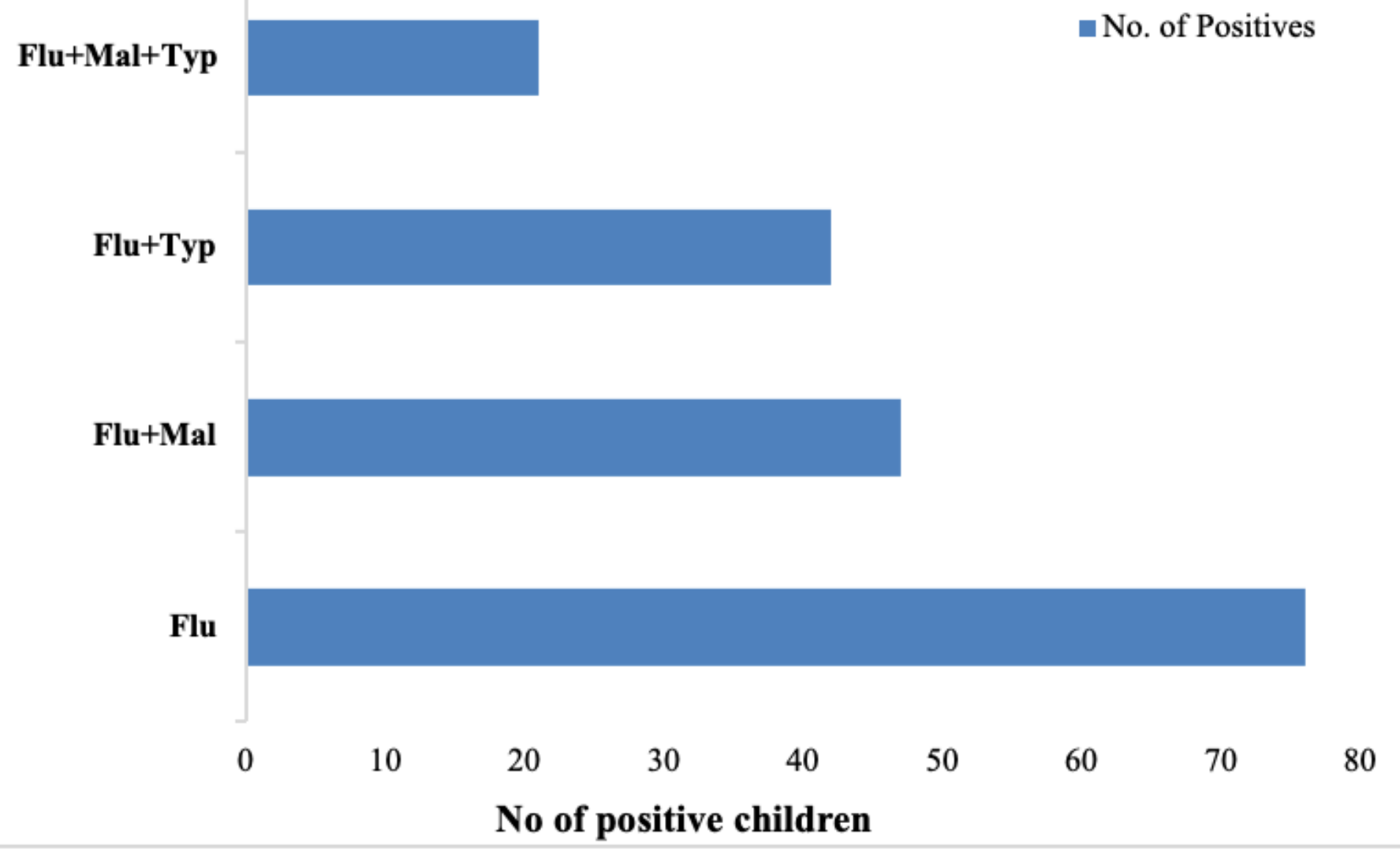

Figure 2 
Distribution of Influenza coinfection with Malaria parasitaemia and Typhoid fever among Healthcare attendee Children in Lagos, Nigeria. Legend: Flu, influenza; Mal, malaria; Typ, typhoid.

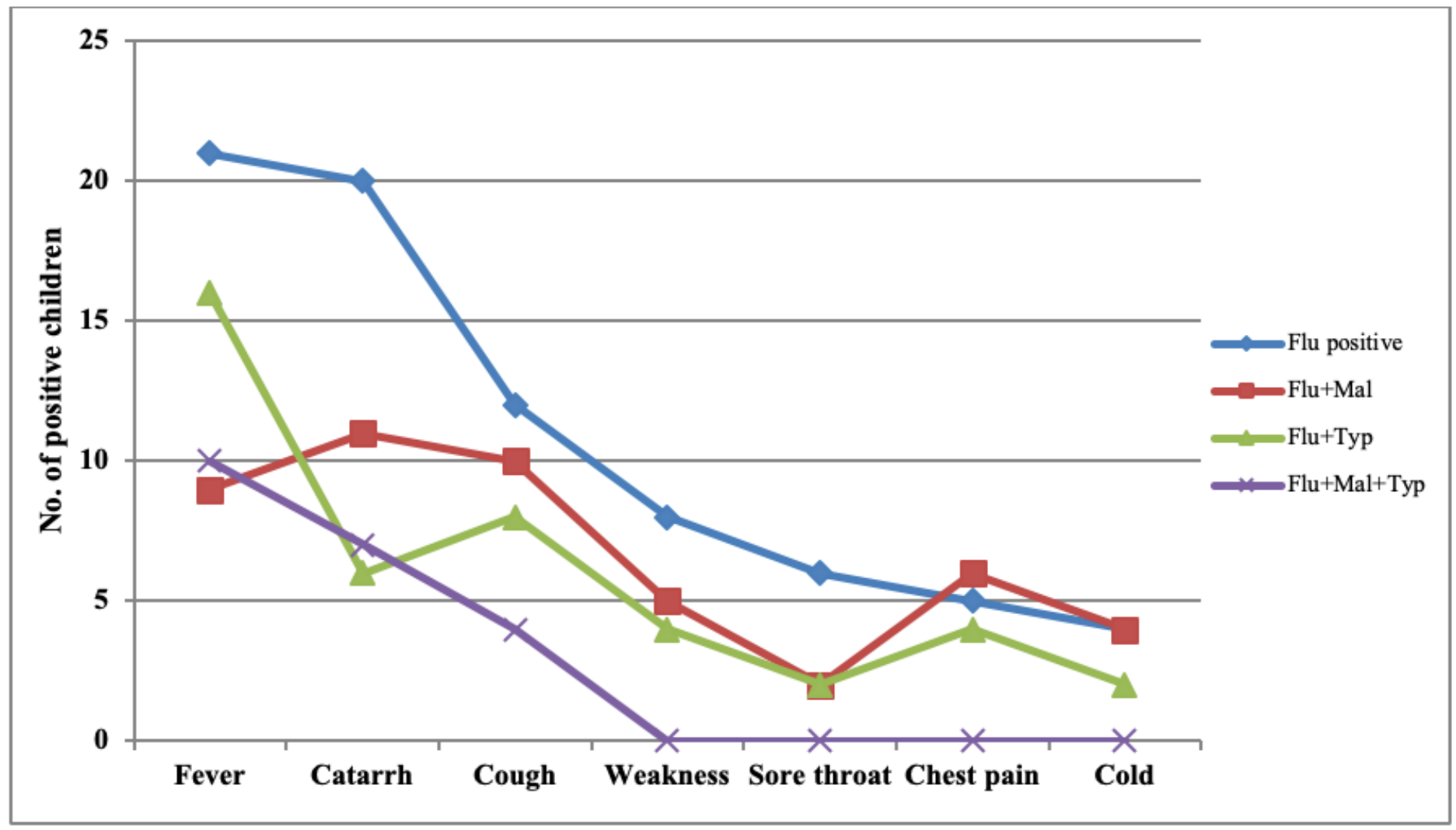

\section{Figure 3}

Distribution of clinical symptoms among children having coinfection of influenza, malaria parasitaemia and typhoid fever in Lagos, Nigeria. 


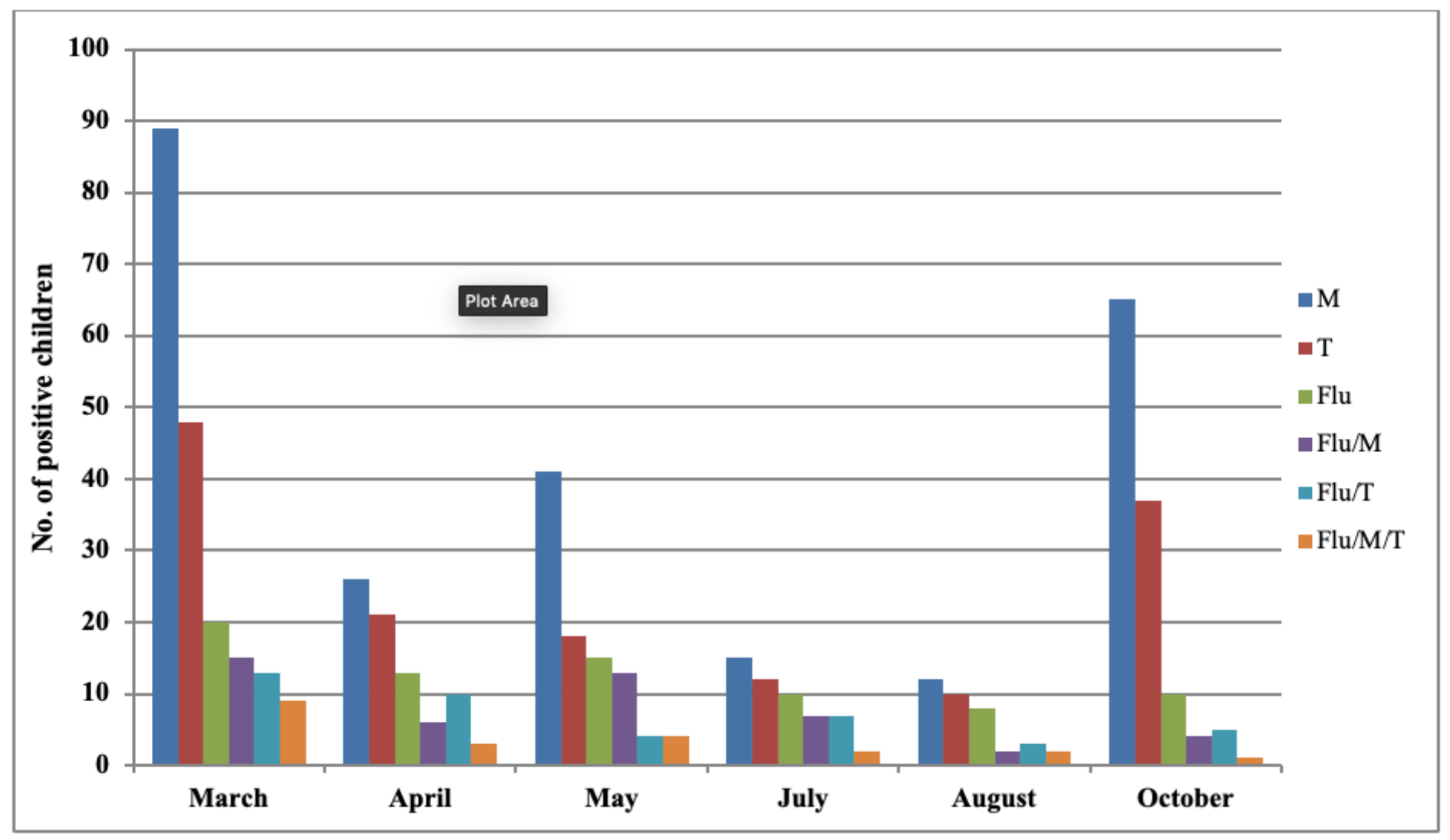

Figure 4

Distribution of Influenza, Malaria parasitaemia and Typhoid fever coinfection in Children from March to October in Lagos, Nigeria. 